\title{
Gigantism caused by growth hormone secreting pituitary adenoma
}

\author{
Noorisaem Rhee, MD, \\ Kumi Jeong, MD, \\ Eun Mi Yang, MD, \\ Chan Jong Kim, MD
}

Department of Pediatrics, Chonnam

National University Hospital \&

Medical School, Gwangju, Korea
Received: 4 February, 2014

Revised: 17 March, 2014

Accepted: 18 March, 2014

Address for correspondence:

Chan Jong Kim, MD

Department of Pediatrics, Chonnam

National University Hospital \&

Medical School, 42 Jebong-ro,

Dong-gu, Gwangju 501-757, Korea

Tel: +82-62-220-6645

Fax: +82-62-222-6103

E-mail: cjkim@jnu.ac.kr
Gigantism indicates excessive secretion of growth hormones (GH) during childhood when open epiphyseal growth plates allow for excessive linear growth. Case one involved a 14.7-year-old boy presented with extreme tall stature. His random serum GH level was $38.4 \mathrm{ng} / \mathrm{mL}$, and failure of $\mathrm{GH}$ suppression was noted during an oral glucose tolerance test (OGTT; nadir serum $\mathrm{GH}, 22.7 \mathrm{ng} / \mathrm{mL}$ ). Magnetic resonance imaging (MRI) of the brain revealed a 12-mm-sized pituitary adenoma. Transsphenoidal surgery was performed and a pituitary adenoma displaying positive immunohistochemical staining for GH was reported. Pituitary MRI scan was performed 4 months after surgery and showed recurrence/residual tumor. Medical treatment with a long-acting somatostatin analogue for six months was unsuccessful. As a result, secondary surgery was performed. Three months after reoperation, the GH level was $0.2 \mathrm{ng} / \mathrm{mL}$ and insulin-like growth factor 1 was 205 $\mathrm{ng} / \mathrm{mL}$. Case two involved a 14.9-year-old boy, who was referred to our department for his tall stature. His basal GH level was $9.3 \mathrm{ng} / \mathrm{mL}$, and failure of $\mathrm{GH}$ suppression was reported during OGTT (nadir GH, $9.0 \mathrm{ng} / \mathrm{mL}$ ). Pituitary MRI showed a 6-mmsized pituitary adenoma. Surgery was done and histopathological examination demonstrated a pituitary adenoma with positive staining for $\mathrm{GH}$. Three months after surgery, the GH level was $0.2 \mathrm{ng} / \mathrm{mL}$ and nadir GH during OGTT was less than $0.1 \mathrm{ng} / \mathrm{mL}$. Pituitary MRI scans showed no residual tumor. We present two cases of gigantism caused by a $\mathrm{GH}$-secreting pituitary adenoma with clinical and microscopic findings.

Keywords: Gigantism, Pituitary adenoma, Growth hormone

\section{Introduction}

Gigantism refers to excessive secretion of growth hormones (GH) that occurs during childhood when epiphyseal growth plates allow for excessive linear growth. On the other hand, acromegaly is the same phenomenon as gigantism but occurring in adulthood ${ }^{1)}$. These two disorders may partially overlap depending on the developmental stage. Approximately $10 \%$ of acromegalics are shown to exhibit tall stature and the majority of giants eventually demonstrate the features of acromegaly $y^{2}$. The mean age for the onset of acromegaly is within the 3 rd decade of life, whereas gigantism may begin at any age prior to epiphyseal fusion ${ }^{1)}$. True gigantism is extremely rare, and it is usually caused by a pituitary adenoma ${ }^{3-5}$.

Pituitary adenomas occur with an annual incidence of 20 cases per million, with adenomas derived from somatotrophs and secreting GH accounting for 3 cases per million ${ }^{6}$. GHsecreting adenomas seem to be more invasive and aggressive in children than in adults ${ }^{5,7)}$. Surgery has traditionally been the first line of treatment, with radiation reserved for inoperable cases. Also, medical therapy has taken on an important role in the management of patients with GH excess with development of somatostatin analogues ${ }^{8}$. We present two cases of gigantism caused by a $\mathrm{GH}$-secreting pituitary adenoma with clinical and microscopic findings. 


\section{Case reports}

\section{Case 1}

A 14.7-year-old boy was presented to Chonnam National University Hospital because of extremely tall stature. His height was $192.0 \mathrm{~cm}(14 \mathrm{~cm}$ above the 97 th percentile $)$ and body weight was $70.5 \mathrm{~kg}$ (90th-97th percentile). He showed enlarged hands and feet, and prognathic mandibles. His body proportion was normal and his pubertal stage was mature (Tanner stage 5). Bone age was normal for chronological age according to the method of Greulich and Pyle ${ }^{9)}$. There was no family history of tall stature (father, $176.0 \mathrm{~cm}$; mother, $167.0 \mathrm{~cm}$ ) or any endocrine diseases. Laboratory investigation showed the following results; random serum GH, $38.4 \mathrm{ng} / \mathrm{mL}$ (normal range, $0-5 \mathrm{ng} / \mathrm{mL}$ ); insulin-like growth factor 1 (IGF-1), 624.0 $\mathrm{ng} / \mathrm{mL}$ (normal range for age, $220-616 \mathrm{ng} / \mathrm{mL}$ ); IGF-BP-3, $6,301.6 \mathrm{ng} / \mathrm{mL}$ (normal range for age, 2,200-5,900 ng/mL); and prolactin, $8.94 \mathrm{ng} / \mathrm{mL}$ (normal range, $3-18 \mathrm{ng} / \mathrm{mL}$ ). GH failed to suppress during an oral glucose tolerance test (OGTT; nadir serum GH, $22.7 \mathrm{ng} / \mathrm{mL}$ [normal range, $<1 \mathrm{ng} / \mathrm{mL}$ ]). Magnetic resonance imaging (MRI) of the brain revealed a $12-\mathrm{mm}$-sized pituitary adenoma (Fig. 1A). Neither pituitary insufficiency nor visual impairment was present. Transsphenoidal surgery was perfor-med and a pathologist reported a pituitary adenoma with positive immunohistochemical staining for GH (Fig. 1B). A pituitary MRI scan performed 4 months after surgery showed recurrence/residual tumor with a size of $5 \mathrm{~mm}$ and a basal $\mathrm{GH}$ level of $7.1 \mathrm{ng} / \mathrm{mL}$ (normal range, $0-5 \mathrm{ng} / \mathrm{mL}$ ). Medical treatment with intramuscular injection of the long-acting somatostatin analogue octreotide LAR (Sandostatin LAR, Novartis Pharma AG, Basle, Switzerland) at a dose of $20 \mathrm{mg}$ was given every 4 weeks. Six months after medical treatment, the serum GH levels increased further, and nadir GH during
OGTT was $6.6 \mathrm{ng} / \mathrm{mL}$ (normal range, $<1 \mathrm{ng} / \mathrm{mL}$ ). Therefore, the patient underwent secondary surgery. Three months after reoperation, the GH level was $0.2 \mathrm{ng} / \mathrm{mL}$ and IGF- 1 was $205 \mathrm{ng}$ / $\mathrm{mL}$ (normal range, 220-616 ng/mL). During 2 years' follow-up, adrenal, gonadal and thyroid functions remained unchanged and annual MRI showed no signs of relapse. GH and IGF-1 levels also showed within normal range. His height was 200.8 $\mathrm{cm}$ ( $>97$ th percentile) at age of 16.7 years.

\section{Case 2}

A 14.9-year-old boy was referred to our pediatric clinic due to extremely tall stature. His height was $197.3 \mathrm{~cm}(19 \mathrm{~cm}$ above the 97th percentile) and body weight was $101.5 \mathrm{~kg}$ (20 kg above the 97 th percentile). He showed enlarged hands and feet, and prognathic mandibles. His body proportion was normal. The pubertal status was mature (Tanner stage 5). He showed advanced bone age of 16.0 years according to the method of Greulich and Pyle ${ }^{9)}$. There was no family history of tall stature (father, $175.0 \mathrm{~cm}$; mother, $163.0 \mathrm{~cm}$ ) or any endocrine diseases. Endocrine investigation revealed the following: basal serum GH, $9.3 \mathrm{ng} / \mathrm{mL}$ (normal range, 0-5 ng/mL); IGF-1, $518.0 \mathrm{ng} / \mathrm{mL}$ (normal range for age, $220-616 \mathrm{ng} / \mathrm{mL}$ ); IGF-BP-3, 3,450.0 ng/ $\mathrm{mL}$ (normal range for age, 2,200-5,900 $\mathrm{ng} / \mathrm{mL}$ ); and prolactin, $10.39 \mathrm{ng} / \mathrm{mL}$ (normal range, $3-18 \mathrm{ng} / \mathrm{mL}$ ). GH failed to suppress during an OGTT (nadir serum GH, $9.0 \mathrm{ng} / \mathrm{mL}$ [normal range, $<1 \mathrm{ng} / \mathrm{mL}]$ ). A pituitary MRI scan showed a $6-\mathrm{mm}$ sized pituitary adenoma (Fig. 2A). Transsphenoidal surgery was performed and histopathological examination demonstrated a pituitary adenoma with positive immunohistochemical staining for $\mathrm{GH}$ (Fig. 2B). Three months after surgery, the GH level was $0.2 \mathrm{ng} / \mathrm{mL}$ (normal range, $0-5 \mathrm{ng} / \mathrm{mL}$ ) and nadir $\mathrm{GH}$ during OGTT was less than $0.1 \mathrm{ng} / \mathrm{mL}$ (normal range, $<1 \mathrm{ng}$ / $\mathrm{mL}$ ). Pituitary MRI scans at 6 months postsurgery showed no

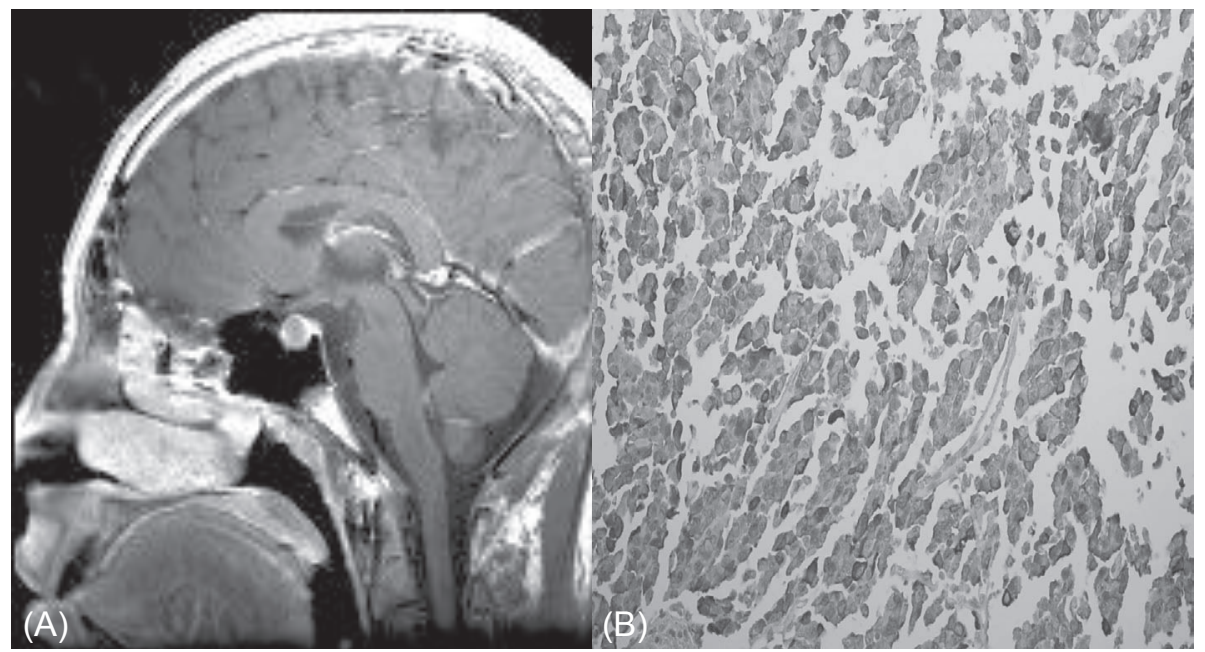

Fig. 1. Contrast enhanced $T 1$ weighted brain magnetic resonance imaging revealed a 12-mm-sized isointense mass in the pituitary gland (A). A formalin fixed section (B) was immunostained with antibodies against human growth hormone $(\mathrm{GH})$, prolactin, thyroid stimulating hormone beta-subunit, and glycoprotein hormone alpha-subunit. GHimmunopositive cells were common (Immunostain, $\times 400$ ). 


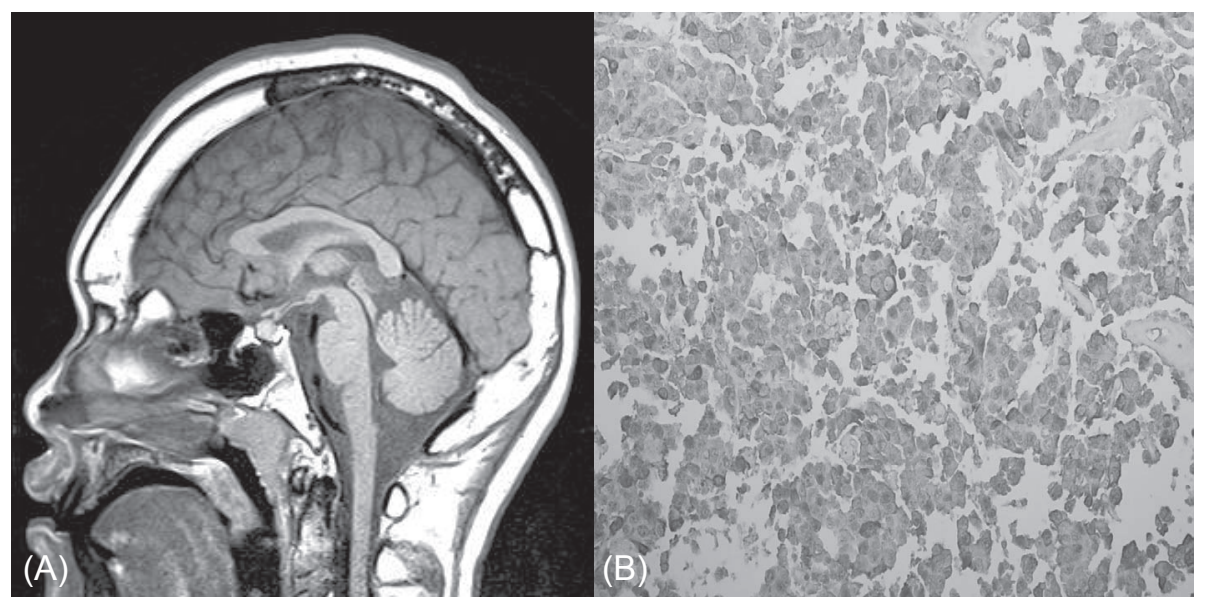

Fig. 2. Sagittal T1 weighted brain magnetic resonance imaging revealed an isointense mass ( $6 \mathrm{~mm}$ ) on pituitary gland (A). A formalin fixed section (B) was immunostained with antibodies against human growth hormone (GH), prolactin, thyroid stimulating hormone beta-subunit, and glycoprotein hormone alpha-subunit. GH-immunopositive cells were common (Immunostain, $\times 400)$.

residual tumor. During 4 years' follow-up, adrenal, gonadal and thyroid functions remained unchanged and annual MRI showed no signs of relapse. GH and IGF-1 levels also showed within normal range. His final height was $206.0 \mathrm{~cm}$ ( $>97 \mathrm{th}$ percentile) at age of 19 years.

\section{Discussion}

Hypersecretion of GH in childhood causes gigantism with potential clinical symptoms including accelerated growth velocity with tall stature, enlargement of the hands and feet, coarsening of facial features, and headaches. Most cases are caused by benign pituitary adenomas ${ }^{3-5)}$. Pituitary gigantism is very rare and the description of the disease is limited to small series and case reports. Approximately 100 cases of children with pituitary gigantism have been reported ${ }^{5,10,11)}$. The median age at diagnosis is 12 years, even though the median age of initial signs and symptoms is 8 years. Even a congenital onset of GH excess has been suggested by linear growth acceleration occurring within the first month of life in children with documented gigantism ${ }^{11)}$. There are a few cases of pituitary gigantism have been reported in Korean children and adolescents ${ }^{12,13}$. Our patients were 14 years of age at the time of diagnosis and presented with extremely tall stature.

Biochemical features of children with gigantism are similar to those of acromegalic adults including elevations in serum $\mathrm{GH}$ and IGF-1 levels, and failure to suppress GH level after OGTT. $\mathrm{GH}$ level is reflective of neurosecretory dysfunction which is characteristic of GH-cell adenomas ${ }^{14)}$, while IGF-1 level provides a surrogate marker of peripheral GH bioactivity ${ }^{15)}$. The gold standard for making the diagnosis of GH excess is failure to suppress serum GH level to less than $1 \mathrm{ng} / \mathrm{mL}$ after OGTT ${ }^{1}$. Hyperprolactinemia is a common finding in GH excess presenting in childhood, undoubtedly related to the fact that mammosomatotrophs (GH and prolactin-secreting cells) are by far the most common type of GH secreting cells involved in childhood gigantism ${ }^{1}$. However, gigantism caused by a pituitary tumor comprised of somatotropes (GH-secreting cells) show a normal prolactin level ${ }^{1)}$. Pituitary imaging by MRI or computed tomography is an essential step in the evaluation following biochemical detection of $\mathrm{GH}$ excess.

Several therapeutic modalities have been used for the treatment of GH excess. For well-circumscribed pituitary adenomas, transsphenoidal surgery is the recommended treatment and it may be curative $e^{3,5,7)}$. Transshpenoidal pituitary surgery has been shown to be safe in both pediatric patients with gigantism and in adults with acromegaly $y^{5)}$. On the other hand, putative pituitary surgery damage with lifelong hormonal replacement therapy has to be taken into account ${ }^{16)}$.

Radiation therapy, used as adjunctive or primary treatment, has also been moderately successful in inducing normalization of GH level. However, the efficacy of radiation therapy in decreasing GH secretion in acromegalic patients is delayed, with a reduction of approximately $50 \%$ by 2 years and $75 \%$ by 5 years ${ }^{17}$. Another major concern of irradiation is a high incidence of hypopituitarism after therapy ${ }^{1)}$.

The somatotropin analogue, octreotide, has been found to be effective in the treatment of acromeglaic patients with $\mathrm{GH}$ excess. A sustained-release somatostatin analogue has also been shown to be successful in returning GH levels to normal in acromegalic adults with pituitary adenomas ${ }^{18)}$. Octreotide suppressed GH secretion and normalized IGF1 levels in $50 \%-70 \%$ of patients, and reduced the size of the tumor in most patients ${ }^{19)}$. Good results of octreotide therapy have been reported in children ${ }^{11,16)}$. In our patient (case 1), the tumor did not respond well to this treatment. Therefore, he underwent transsphenoidal reoperation. Recently, treatment of acromegaly with a new GH receptor antagonist pegvisomant has been introduced. Pegvisomant is a GH analogue that binds to $\mathrm{GH}$ receptors on the cell surface, and blocks GH receptor 
dimerisation $^{8)}$. Pegvisomant has been effective in acromeglaic patients resistant to somatostatin analogues ${ }^{8)}$. After further studies, pegvisomant might be an additional option for the treatment of pituitary gigantism in children.

In conclusion, we report here two cases of childhood gigantism caused by GH secreting pituitary adenomas. Treatment of pituitary gigantism in childhood is difficult and often unsatisfactory. Our patients should be closely followed up for the potential risk of hypopituitarism.

\section{Conflict of interest}

No potential conflict of interest relevant to this article was reported.

\section{References}

1. Eugster EA, Pescovitz OH. Gigantism. J Clin Endocrinol Metab 1999;84:4379-84.

2. Whitehead EM, Shalet SM, Davies D, Enoch BA, Price DA, Beardwell CG. Pituitary gigantism: a disabling condition. Clin Endocrinol (Oxf) 1982;17:271-7.

3. Kane LA, Leinung MC, Scheithauer BW, Bergstralh EJ, Laws ER Jr, Groover RV, et al. Pituitary adenomas in childhood and adolescence. J Clin Endocrinol Metab 1994;79:113540 .

4. Artese R, D'Osvaldo DH, Molocznik I, Benencia H, Oviedo J, Burdman JA, et al. Pituitary tumors in adolescent patients. Neurol Res 1998;20:415-7.

5. Abe T, Tara LA, Ludecke DK. Growth hormone-secreting pituitary adenomas in childhood and adolescence: features and results of transnasal surgery. Neurosurgery 1999;45:110.

6. Melmed S, Ho K, Klibanski A, Reichlin S, Thorner M. Clinical review 75: recent advances in pathogenesis, diagnosis, and management of acromegaly. J Clin Endocrinol Metab 1995;80:3395-402.

7. Dyer EH, Civit T, Visot A, Delalande O, Derome P. Transsphenoidal surgery for pituitary adenomas in children. Neurosurgery 1994;34:207-12.

8. Rix M, Laurberg P, Hoejberg AS, Brock-Jacobsen B. Pegvisomant therapy in pituitary gigantism: successful treatment in a 12-year-old girl. Eur J Endocrinol 2005;153:
195-201.

9. Greulich WW, Pyle SI. Radiographic skeletal development of the hand and wrist. 2nd ed. Stanford; Stanford University Press, 1959

10. Pandey P, Ojha BK, Mahapatra AK. Pediatric pituitary adenoma: a series of 42 patients. J Clin Neurosci 2005;12:124-7.

11. Gelber SJ, Heffez DS, Donohoue PA. Pituitary gigantism caused by growth hormone excess from infancy. J Pediatr 1992;120:931-4.

12. Kim HY, Jung HW, Lee J, Yoon JY, Lee YA, Shin CH, et al. Childhood onset pituitary adenoma: clinical presentations and outcomes of 24 cases. Ann Pediatr Endocrinol Metab 2012:17:82-91.

13. Kim EY, Choi JU, Chung SS, Lee KC, Kim DH. Pituitary adenomas in childhood and adolescence. J Korean Neurosurg Soc 1995:24:864-75.

14. Melmed S. Medical progress: acromegaly. N Engl J Med 2006;355:2558-73.

15. Sata A, Ho KK. Growth hormone measurements in the diagnosis and monitoring of acromegaly. Pituitary 2007;10:165-72.

16. Schoof E, Dorr HG, Kiess W, Ludecke DK, Freitag E, Zindel $\mathrm{V}$, et al. Five-year follow-up of a 13-year-old boy with a pituitary adenoma causing gigantism: effect of octreotide therapy. Horm Res 2004;61:184-9.

17. Barrande G, Pittino-Lungo M, Coste J, Ponvert D, Bertagna $\mathrm{X}$, Luton JP, et al. Hormonal and metabolic effects of radiotherapy in acromegaly: long-term results in 128 patients followed in a single center. J Clin Endocrinol Metab 2000;85:3779-85.

18. Ayuk J, Stewart SE, Stewart PM, Sheppard MC; European Sandostatin LAR Group. Efficacy of Sandostatin LAR (long-acting somatostatin analogue) is similar in patients with untreated acromegaly and in those previously treated with surgery and/or radiotherapy. Clin Endocrinol (Oxf) 2004;60:375-81.

19. Bevan JS, Atkin SL, Atkinson AB, Bouloux PM, Hanna F, Harris PE, et al. Primary medical therapy for acromegaly: an open, prospective, multicenter study of the effects of subcutaneous and intramuscular slow-release octreotide on growth hormone, insulin-like growth factor-I, and tumor size. J Clin Endocrinol Metab 2002;87:4554-63. 